\title{
Disease Severity and Microsclerotium Properties of the Sorghum Sooty Stripe Pathogen, Ramulispora sorghi
}

C. R. Brady and L. W. Noll, Department of Plant Pathology, Kansas State University, Manhattan; A. A. Saleh, Department of Plant Protection, King Saud University, Riyadh, Kingdom of Saudi Arabia; and C. R. Little, Department of Plant Pathology, Kansas State University, Manhattan

\begin{abstract}
Brady, C. R., Noll, L. W., Saleh, A. A., and Little, C. R. 2011. Disease severity and microsclerotium properties of the sorghum sooty stripe pathogen, Ramulispora sorghi. Plant Dis. 95:853-859.

Ramulispora sorghi causes sooty stripe of sorghum. Disease severity in irrigated and dryland plots was measured for 25 susceptible sorghum genotypes during the 2007 and 2008 growing seasons using a rating scale based upon percent leaf area infected. Disease severity ratings were approximately 1.4 points higher $(P<0.0001)$ on the rating scale in the irrigated plots than dryland plots for 2007 and 2008. Sooty stripe lesions were collected from each sorghum genotype in irrigated plots and assessed for mean microsclerotium production within lesions, microsclerotium size, and sporogenic germination, with significant differences apparent between genotypes for microsclerotium size $(P=$ $0.01)$ and sporogenic germination $(P=0.01)$. There was no relation-

ship between disease severity and microsclerotium production within leaf lesions, microsclerotium size, or sporogenic germination; however, there was a positive and significant correlation between microsclerotia production within a lesion and microsclerotium size $\left(R^{2}=0.19, P<\right.$ 0.0001 ). Although microsclerotia from sorghum lesions varied in structural characteristics and their ability to produce spore masses, these qualities were dependent upon the sorghum genotype from which the microsclerotia were derived, because the $R$. sorghi population was genetically uniform as determined by internal transcribed spacer sequences and random amplified polymorphic DNA polymerase chain reaction
\end{abstract}

Ramulispora sorghi (Ellis \& Everh.) L.S. Olive \& Lefebvre causes sooty stripe of Sorghum spp. (cultivated sorghum, Columbus grass, Johnsongrass, and Sudangrass) and produces leaf spots on Agrostis spp. (creeping bentgrass, colonial bentgrass, redtop, and velvet bentgrass), Arthraxon hispidus (carpgrass), and Setaria italica (foxtail bristlegrass) $(7,15,23,25,27,31-33)$. This fungus typifies its own clade within the Mycosphaerellaceae, being most closely related to Cercosporella, Cercospora, and Septoria spp. $(4,5)$.

Sooty stripe in cultivated sorghum (Sorghum bicolor (L.) Moench) is an important leaf disease in many sorghum-producing regions. Sooty stripe can cause serious yield losses in Africa and India, and is present throughout the United States, where losses are reported in certain hybrids $(1,6,11,14,18,20,21,24,28)$. For example, epidemics of sooty stripe have occurred in Kansas and resulted in field incidences of $80 \%$ and yield losses of 10 to $26 \%$ in susceptible hybrids $(11,29,35)$.

Sooty stripe lesions are oval-elongate, surrounded by a prominent chlorotic halo, and characterized by the production of numerous microsclerotia $(4,10,28)$. $R$. sorghi microsclerotia are small subspherical hyphal structures characterized by expanding radial growth, a rough brown to black surface, and growth in linear clusters along and between leaf veins (Fig. 1). These structures do not possess defined tissue types or layers, as observed in the welldifferentiated sclerotia produced by Sclerotium rolfsii, for example. Microsclerotia are composed of compact pseudoparenchymatous cells. Microsclerotia are derived from erumpent masses of subepidermal stromata and function to facilitate overwintering of the

Corresponding author: C. R. Little, E-mail: crlittle@ksu.edu

This article is contribution number 11-159-J from the Kansas Agricultural Experiment Station, Manhattan.

Accepted for publication 17 March 2011.

doi:10.1094/PDIS-10-10-0742

(C) 2011 The American Phytopathological Society pathogen on soil surfaces, within plant debris, and, to a lesser degree, buried within the soil $(10,22)$. In sooty stripe disease, microsclerotia of $R$. sorghi serve as a key source of viability (survival) and represent inoculum potential for the pathogen. In the spring, microsclerotia germinate gelatinous spore masses, where the uniquely branched (euseptate, scolecosporous) conidia act as primary inoculum to initiate foliar infections (5,22; Fig. 2).

The goal of this study was to determine (i) the disease severity of sooty stripe in dryland and irrigated plots across diverse sorghum genotypes, (ii) the influence of sorghum genotype upon

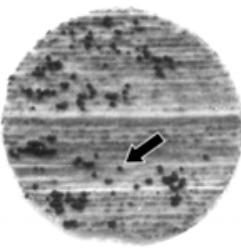

Minimum

(SC452)

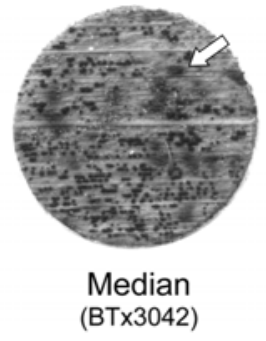

(BT×3042)

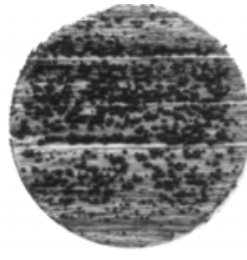

Maximum

(SC62)
Fig. 1. Examples of three 6-mm-diameter $\left(28.3 \mathrm{~mm}^{2}\right)$ leaf disk sections excised from sooty stripe lesion centers. These leaf disks represent examples of the minimum ('SC452'), median ('BTX3042'), and maximum ('SC62') numbers of Ramulispora sorghi microsclerotia (black arrow) per square millimeter of lesion area. The white arrow points to an accumulation of plant pigments in the leaf tissue.

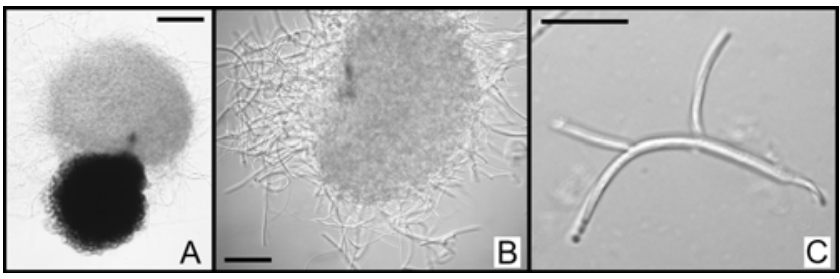

Fig. 2. Ramulispora sorghi. A, Dark, melanized microsclerotium with emerging spore mass ("sporogenic germination"); B, dislodged spore mass; and C, characteristically branched conidium. In each panel, lengths of scale bars are 60 (A), 30 (B), and $10 \mu \mathrm{m}(\mathrm{C})$. 
microsclerotium production within sooty stripe lesions, and (iii) the influence of sorghum genotype upon size of and spore mass germination by microsclerotia.

\section{Materials and Methods}

Environment. Weather data were obtained throughout the growing seasons in 2007 and 2008 from the Kansas State University weather station in Manhattan, KS (http://www.ksre.ksu.edu/wdl/). In 2007, Manhattan had $39.8 \mathrm{~cm}$ of precipitation during the growing season (June to October), which was lower than the norm (1970 to present) of $48.5 \mathrm{~cm}$ for the same period. However, the rainfall for May 2007 was more than twice the normal for the same month (11.4 cm; data not shown). In 2008, Manhattan had nearly twice the amount of precipitation for the growing season as in 2007, with increases in accumulation during August and September (Table 1). Minimum and maximum air temperatures were cooler in 2008 than in 2007, especially in August and September, where average maximum daily temperatures were more than $1{ }^{\circ} \mathrm{C}$ cooler. On average, relative humidity $(\mathrm{RH})$ values were $1.6 \%$ higher over the growing period during 2008 versus the previous year, with September 2008 having $6.7 \%$ higher average RH than the same month in 2007.

Disease severity. Of a 300-genotype sorghum "diversity panel" grown in Manhattan (Ashland Bottoms Research Farm, Kansas State University) for 2 years (2007 and 2008), 25 genotypes susceptible to sooty stripe disease, showing lesions, and producing microsclerotia were specifically chosen for closer investigation. The diversity panel was planted as a completely randomized design (genotypes) within a dryland and an irrigated environment. The chosen sorghum genotypes were evaluated prior to harvest on 15 September 2007 and 21 September 2008 for disease severity from natural inoculum in both the dryland and irrigated plots (each line was replicated twice within both environments). For irrigated plots, two applications of 10 to $15 \mathrm{~cm}$ of water were applied by flooding during the growing season. Disease severity was assessed for a total of 10 plants ( 5 plants per row for two replicated rows) within dryland and irrigated plots for both years using the rating scale described by Thomas et al. (32) (e.g., $1=$ no symptoms, $2=$ up to $5,3=6$ to $25,4=26$ to $50,5=51$ to 75 , and $6=>75 \%$ leaf area infected).

In the 2007 irrigated plots, symptomatic leaves were collected from the middle canopy of each of the chosen sorghum genotypes approximately 2 weeks before grain harvest. For a particular genotype, leaf samples were collected from both ends and the center of each of the two replicated genotype rows. Leaves with sooty stripe lesions were dried, pressed, and stored at room temperature. This material was used to measure microsclerotium production, size, and percent sporogenic germination of microsclerotia obtained from each sorghum genotype.

Microsclerotia production within lesions. Leaf disks from leaf sample lesions of three to six different plants (collected as described above) were dissected from the centers of sooty stripe lesions using a 6-mm cork-borer $\left(28.3 \mathrm{~mm}^{2}\right.$ surface area) from each of the 25 sorghum genotypes collected (Fig. 1). Each leaf disk sample was scanned at 2,561 dpi using an Epson 3200 color scanner and images were maintained as ".tif" files (Adobe Photoshop Elements, v. 2.0). Each scanned leaf disk sample was used to obtain the total microsclerotium count, average sample diameter, and average microsclerotium diameter. Using these images, total microsclerotia in each leaf disk were manually marked, counted, and converted to a microsclerotia per square millimeter value by dividing by the total leaf disc area.

Microsclerotium size. Microsclerotia size (in situ) was measured using Adobe Photoshop Elements (v. 2.0). Leaf disk sample (see above) diameters were measured by taking a single horizontaland vertical-row pixel count of each leaf disk. Based on this, an average value of $9.77 \mu \mathrm{m} /$ pixel at a maximum scanning resolution of 2,561 pixels/inch per leaf disk image was obtained as a conversion factor. In order to obtain mean microsclerotium size, the diameter of 30 microsclerotia on each leaf disk image was measured in pixels and then converted to micrometers using the conversion factor of $9.77 \mu \mathrm{m}$ per pixel.

Sporogenic germination of microsclerotia. In total, 100 microsclerotia from each of the 25 sorghum genotypes were harvested from lesions with a flame-sterilized pair of tweezers under the dissecting microscope. To avoid germination of contaminating phyllosphere fungi associated with $R$. sorghi microsclerotia, the fungal bodies were surface sterilized in a $10 \%$ (vol/vol) household bleach solution for $10 \mathrm{~min}$ and then rinsed twice in sterile distilled water for an additional $10 \mathrm{~min}$ per rinse. Ten surface-sterilized microsclerotia were placed on one-half-strength potato dextrose agar (1/2-PDA) amended with streptomycin sulfate at $50 \mu \mathrm{g} / \mathrm{ml}$, penicillin " $G$ " sodium salt at $20 \mu \mathrm{g} / \mathrm{ml}$, and chlorotetracycline hydrochloride at $100 \mu \mathrm{g} / \mathrm{ml}$. Plates were incubated at $25^{\circ} \mathrm{C}$ for 9 to 15 days to produce spore masses (Fig. 2).

Disease severity, microsclerotium production within disease lesions, microsclerotium size, and sporogenic germination of microsclerotia was analyzed using analysis of variance (JMP 7.01; SAS Inc.; 12). Also, for disease severity, comparisons of genotypes with 'BTx3042', the susceptible check cultivar, were made using Dunnett's test at $P<0.05$ (JMP 7.01; SAS Inc.; 12).

Single-spore isolation. Once a microsclerotium had produced a spore mass, the conidia were spread onto a new $1 / 2$-PDA plate using a rolling action with a flame-sterilized dissecting needle in order to separate conidia. Using an agar block-transfer technique, single conidia were transferred to $1 / 2$-PDA plates and incubated at $25^{\circ} \mathrm{C}$ for 30 days in order to produce a sufficient colony for DNA extraction (see below). Single-spore isolates were assigned the prefix " $R s$ " and the sorghum genotype from which the generative microsclerotium was obtained; for example, "RsBTx3042". All isolates were preserved in $15 \%$ glycerol stocks at $-80^{\circ} \mathrm{C}$.

DNA extraction. Single-spore colonies $(20 \mathrm{~mm}$ in diameter $)$ were shaved from the media surface and ground to a fine powder using liquid nitrogen. DNA was extracted using a modified $2 \%$ cetyltrimethylammonium bromide buffer protocol for fungi $(13,19)$.

Internal transcribed spacer sequencing. In order to confirm the identity of the $R$. sorghi isolates, polymerase chain reaction

Table 1. Growth season weather data from Manhattan, KS in 2007 and $2008^{\mathrm{a}}$

\begin{tabular}{|c|c|c|c|c|c|c|c|c|}
\hline \multirow[b]{3}{*}{ Month } & \multicolumn{4}{|c|}{ Air temperature $\left({ }^{\circ} \mathbf{C}\right)$} & \multirow{2}{*}{\multicolumn{2}{|c|}{ Total precipitation $(\mathbf{c m})$}} & \multirow{2}{*}{\multicolumn{2}{|c|}{ Relative humidity (\%) }} \\
\hline & \multicolumn{2}{|c|}{ Maximum } & \multicolumn{2}{|c|}{ Minimum } & & & & \\
\hline & 2007 & 2008 & 2007 & 2008 & 2007 & 2008 & 2007 & 2008 \\
\hline June & 27.3 & 29.7 & 18.2 & 17.1 & 9.3 & 30.4 & 73.6 & 73.4 \\
\hline July & 31.7 & 31.9 & 19.4 & 23.9 & 10.5 & 12.9 & 75.9 & 74.9 \\
\hline August & 34.3 & 30.3 & 21.8 & 17.3 & 5.5 & 11.7 & 73.3 & 74.3 \\
\hline September & 28.1 & 25.4 & 13.8 & 12.7 & 4.4 & 17.8 & 70.9 & 77.6 \\
\hline October & 22.4 & 20.1 & 8.6 & 5.8 & 10.1 & 5.2 & 69.9 & 71.3 \\
\hline Seasonal ${ }^{\mathrm{b}}$ & 28.9 & 27.5 & 16.3 & 14.5 & 39.8 & 78.0 & 72.7 & 74.3 \\
\hline
\end{tabular}

a Weather data was obtained throughout the growing season from the Kansas State University weather station at Manhattan, KS (http://www.ksre.ksu.edu/ $\mathrm{wdl} /)$.

${ }^{\mathrm{b}}$ Seasonal mean for temperature and humidity, and seasonal total for precipitation. 
(PCR) amplification of a portion of the internal transcribed spacer (ITS) was conducted and the resulting sequences compared with those in the National Center for Biotechnology Information (NCBI) database. For ITS PCR, $2.0 \mu \mathrm{l}(5 \mathrm{pmol} / \mu \mathrm{l})$ of each ITS primer (ITS4 [5'-TCCTCCGCTTATTGATATGC-3'] and ITS5 [5'GGAAGTAAAAGTCGTAACAA-3']) was used to amplify the ITS-5.8S rDNA region (34). Standard PCR mixes (1.0 $\mu \mathrm{l}$ of target DNA [15 ng/ $\mu \mathrm{l}$ ], $0.1 \mu \mathrm{l}$ of Taq polymerase [5 units/ $\mu \mathrm{l}], 2.0 \mu \mathrm{l}$ of 2 $\mathrm{mM}$ dNTPs, $2.0 \mu \mathrm{l}$ of $15 \mathrm{mM} \mathrm{MgCl} 2$, and $1.0 \mu \mathrm{l}$ of $10 \times$ PCR buffer [Bioline, London]) diluted to $20 \mu \mathrm{l}$ of total volume with doubledistilled (dd) $\mathrm{H}_{2} \mathrm{O}$ and PCR conditions of $94^{\circ} \mathrm{C}$ melting $(30 \mathrm{~s}), 62^{\circ} \mathrm{C}$ annealing $(45 \mathrm{~s})$, and $72^{\circ} \mathrm{C}$ extension temperatures $(1 \mathrm{~min})$ for 35 cycles were used to amplify the region using a Techne T-3000 thermocycler (Techne Ltd., Cambridge).

Unincorporated primers, free nucleotides, and PCR buffer were removed using QIAquick spin columns (Qiagen, Valencia, CA). PCR products from six $R$. sorghi isolates $(R s S C 303, R s S C 261$, $R s \mathrm{SC} 968, R s \mathrm{BT} \times 378, R s$ Day, and $R s$ Combine) were sequenced at the Kansas State University sequencing facility. Sequences were edited manually using BioEdit (v. 7.0.9.0) (8). Sequences have been deposited in the NCBI database (GenBank accessions HQ400740 to HQ400745). Sequences were aligned using ClustalW (Conway Institute, UCD, Dublin).

Random amplified polymorphic DNA fingerprinting. Four random amplified polymorphic DNA (RAPD) primers (OPE-2 5'GGTGCGGGAA-3', OPE-3 5'-CCAGATGCAC-3', OPE-14 5' TGCGGCTGAG-3', and OPE-15 5'-ACGCACAACC-3'; Kit E, Operon Technologies Inc., Alameda, CA) were used to amplify DNA from $24 R$. sorghi isolates. OPE-14 and OPE-15 were chosen because of their ability to distinguish isolates of $R$. herpotrichoides (3); OPE-2 and OPE-3 were also included in the aforementioned study. No previous studies have examined RAPDs in $R$. sorghi. RsSC609 was not included in the RAPD analysis due to insufficient sporogenic germination by microsclerotia produced from 'SC609' lesions. A standard PCR mix (1.0 $\mu$ l of target DNA [15 $\mathrm{ng} / \mu \mathrm{l}$ ], $2.0 \mu \mathrm{l}$ of OPE primer [described above; $5 \mathrm{pmol} / \mu \mathrm{l}$ ], $0.1 \mu \mathrm{l}$ of Taq polymerase [5 units/ $\mu \mathrm{l}$ ], $2.0 \mu \mathrm{l}$ of $2 \mathrm{mM}$ dNTPs, $2.0 \mu \mathrm{l}$ of 15 $\mathrm{mM} \mathrm{MgCl}$, and $1.0 \mu \mathrm{l}$ of $10 \times \mathrm{PCR}$ buffer [Bioline]) diluted to a total volume of $18 \mu \mathrm{l}$ with $\mathrm{ddH}_{2} \mathrm{O}$ was used. $\mathrm{PCR}$ conditions were a 1 -min hot start at $94^{\circ} \mathrm{C} ; 40$ cycles at $94^{\circ} \mathrm{C}$ for $1 \mathrm{~min}, 36^{\circ} \mathrm{C}$ for 1 min, and $72^{\circ} \mathrm{C}$ for $1 \mathrm{~min}$; with a final extension step of $72^{\circ} \mathrm{C}$ for 5 min. Amplification products were size fractionated on agarose gels and visualized by staining with ethidium bromide.

\section{Results}

Overall, disease severity was increased $(P=0.0003)$ in 2008 (mean rating of 2.35 for the dryland and 3.72 for irrigated plots) compared with 2007 (mean rating of 2.18 for the dryland and 3.57 for the irrigated plots) (Table 2; Fig. 3). The irrigation-disease severity interaction was significant in both years, and irrigation increased $(P<0.0001)$ disease severity by an average of 1.3 to 1.4 points on the severity scale (Table 2 ; Fig. 3 ). Disease severity varied $(P<0.0001)$ considerably between the sooty stripe-susceptible sorghum genotypes and was also influenced $(P<0.0001)$ by irrigation (Table 2; Fig. 3).

The most susceptible of the chosen sorghum genotypes was BTx3042, which ranked in the upper $10 \%$ of highest disease severity ratings during each year and under each irrigation regime, whereas 'BTx399', the most resistant genotype, consistently fell in the lowest $10 \%$ of disease severity ratings (Fig. 3). Thus, BTx3042 acted as a "susceptible check" relative to the other genotypes. In both years of the study, four genotypes did not differ significantly from BTx3042 in mean disease severity within the irrigated treatments: SC261, SC452, SC855, and SC968 (Dunnett's Test, $P>0.05)$. However, SC261 and SC 855 exhibited very little sooty stripe lesion development under dryland conditions (disease ratings of 1.3 to 1.6$)$ but a significantly $(P<0.0001)$ greater amount under irrigated conditions (5.0 to 5.5) during both years of the study (Fig. 3).

Mean production of $R$. sorghi microsclerotia ranged from an average of 5 (SC452) to 30 (SC62) per square millimeter in sooty stripe lesions, with an overall mean across the susceptible sorghum genotypes of $17 \mathrm{microsclerotia} / \mathrm{mm}^{2}$ within leaf lesions (Fig. 4). However, the differences between the 25 genotypes compared were not significant $(P=0.10)$.

In this study, there was no relationship $(P=0.74)$ between sooty stripe disease severity and microsclerotium production within a lesion. Production of microsclerotia was not uniform on the lesion surface in sorghum genotypes where production was low (ex. SC452) but appeared more uniform on genotypes where production was high (ex. SC62). On some sorghum genotypes, the accumulation of plant pigments was present in the tissues adjacent to rows of microsclerotia (Fig. 1).

Mean diameters of microsclerotia obtained from sooty stripe disease lesions differed significantly $(P=0.01)$ between the 25 genotypes compared and ranged from $87 \mu \mathrm{m}$ (produced on sorghum genotype 'Hegari') to $133 \mu \mathrm{m}$ (produced on SC855), with an overall mean across sorghum genotypes of $110 \mu \mathrm{m}$ (Fig. 4). The relationship between disease severity and size (diameter) of microsclerotia was not significant $\left(R^{2}=0.02, P=0.47\right)$. Likewise, there was not a significant $\left(R^{2}<0.01 ; P=0.90\right)$ relationship between severity and sporogenic germination. Mean sporogenic germination of microsclerotia ranged from 5\% (BTx378) to 90\% (SC452), with an overall mean across sorghum genotypes of approximately $36 \%$.

In this study, there was a positive and significant correlation $\left(R^{2}\right.$ $=0.19, P<0.0001)$ between microsclerotia production within a lesion and microsclerotium size (Fig. 5) but there was no relationship between microsclerotia production $\left(R^{2}=0.03, P=0.46\right)$ or size $\left(R^{2}<0.01, P=0.51\right)$ with sporogenic germination.

The lengths of manually adjusted ITS sequences obtained in this study (GenBank accessions HQ400740 to HQ400745) varied from 425 to $482 \mathrm{bp}$ and covered the ITS1, 5.8S rRNA gene, and ITS2 regions for $R$. sorghi. When sequences were trimmed to common start and end sites, there was $100 \%$ identity of the fragments with the previously published ITS sequences from South African isolates of $R$. sorghi, STE-U 905 (GenBank accession AY259131),

Table 2. Analyses of variance for main effects and their interactions for sooty stripe disease severity in Manhattan, KS during the 2007 and 2008 sorghum growing seasons

\begin{tabular}{|c|c|c|c|c|c|}
\hline Source & DF & SS & MS & $F$ & $P$ \\
\hline Model & 99 & 335.49 & 3.39 & 36.44 & $<0.0001$ \\
\hline Error & 100 & 9.3 & 0.093 & $\ldots$ & $\ldots$ \\
\hline Total & 199 & 344.79 & $\ldots$ & $\ldots$ & $\ldots$ \\
\hline \multicolumn{6}{|l|}{ Effects } \\
\hline Genotype $(\mathrm{G})^{\mathrm{a}}$ & $25-1=24$ & 192.24 & 8.01 & 86.13 & $<0.0001$ \\
\hline Year $(\mathrm{Y})$ & $2-1=1$ & 1.31 & 1.31 & 14.11 & 0.0003 \\
\hline Irrigation (I) & $2-1=1$ & 95.50 & 95.50 & $1,026.84$ & $<0.0001$ \\
\hline $\mathrm{G} \times \mathrm{Y}$ & $24 \times 1=24$ & 3.17 & 0.13 & 1.42 & 0.1164 \\
\hline $\mathrm{G} \times \mathrm{I}$ & $24 \times 1=24$ & 40.73 & 1.70 & 18.25 & $<0.0001$ \\
\hline $\mathrm{Y} \times \mathrm{I}$ & $1 \times 1=1$ & 0.00 & 0.00 & 0.05 & 0.8171 \\
\hline $\mathrm{G} \times \mathrm{Y} \times \mathrm{I}$ & $24 \times 1 \times 1=24$ & 2.54 & 0.11 & 1.14 & 0.3187 \\
\hline
\end{tabular}

${ }^{a}$ Host genotype. 
STE-U 906 (AY259132), and STE-U 908 (AY259133) (4). The OPE-2, OPE-3, OPE-14, and OPE-15 decamer primers resulted in amplification of PCR products, including multiple bands for each primer. For each primer tested, $R$. sorghi isolates showed no polymorphisms between the isolates (Fig. 6).

\section{Discussion}

$R$. sorghi produces numerous microsclerotia, which overseason to produce branched conidia via sporogenic germination (22). Disease severity in irrigated and dryland plots was measured for 25 susceptible sorghum genotypes during the 2007 and 2008 growing seasons using a rating scale based upon percent leaf area infected, as described by Thomas et al. (32). Disease severity ratings were significantly higher $(P<0.0001)$ in the irrigated plots than for the dryland plots in 2007 and 2008. Sooty stripe lesions were collected from each sorghum genotype in irrigated plots and assessed for mean microsclerotium production within lesions, microsclerotium size, and sporogenic germination, with significant differences apparent between genotypes for microsclerotium size $(P=0.01)$ and sporogenic germination $(P=0.01)$. There was no relationship between disease severity and microsclerotium production within leaf lesions, microsclerotium size, or sporogenic germination; however, there was a positive and significant correlation between microsclerotia production within a lesion and microsclerotium size $\left(R^{2}=\right.$
$0.19, P<0.0001)$. Although microsclerotia from sorghum lesions varied significantly in structural characteristics and their ability to produce spore masses, these qualities were dependent upon the sorghum genotype from which the microsclerotia were derived, because the $R$. sorghi population was genetically uniform as determined by ITS sequences and RAPD PCR.

Sooty stripe is a foliar disease of sorghum that is dependent upon environmental conditions, especially moisture, because conidia production and dispersal depends on high relative humidity and splash dispersal, respectively $(9,17,26)$. In this study, irrigation clearly promoted foliar infection (Fig. 3) but little is known concerning the specific relative humidity requirements for $R$. sorghi sporogenic germination or conidial infection of foliage. However, Ngugi et al. (20) showed that different ecological climes favored the development of sooty stripe (semiarid; 25 to $40 \%$ rainfall/potential evapotranspiration [R/PET]) versus anthracnose (warm, humid; $>65 \%$ R/PET) in Kenya. In the same study, it was shown that increased humidity was associated with decreased prevalence of oval leaf spot ( $R$. sorghicola), a disease that increased in prevalence in areas having 50 to $65 \%$ R/PET. In Kansas, sooty stripe disease severity was dramatically greater in irrigated plots but also occurred at relatively high levels in dryland production, although there was an interaction with sorghum genotype in this environment (Fig. 3; Table 2). These results indicate that co-
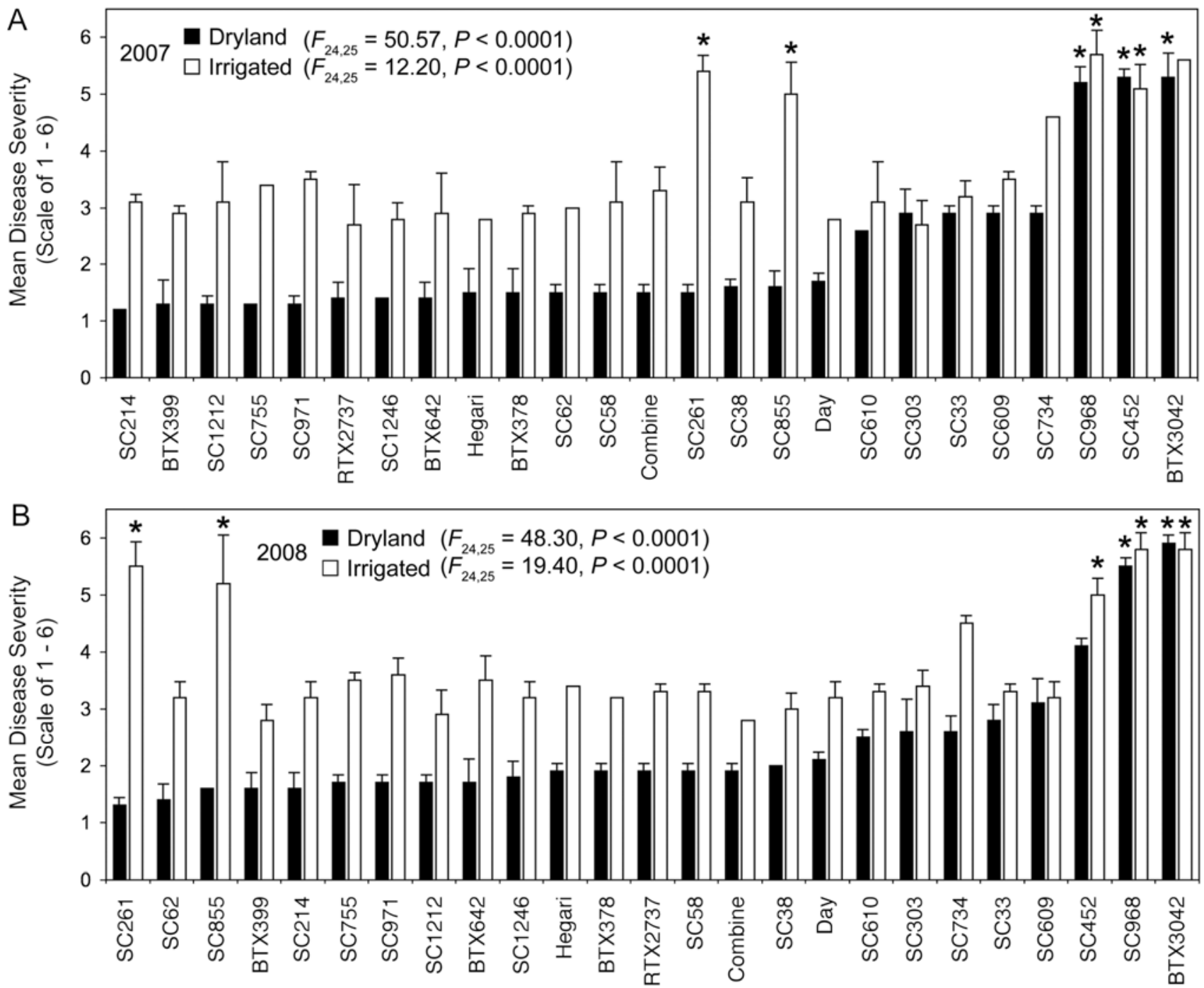

Fig. 3. Mean disease severity of sooty stripe lesions on 25 susceptible sorghum accessions evaluated under dryland and irrigated conditions in Manhattan, KS during A, 2007 and B, 2008. Disease severity was rated on a scale of 1 to 6 (1 = no symptoms to $6=>75 \%$ leaf area infected). Each bar is the mean for five plants in each of two replicated rows in different parts of the same irrigated or dryland field location. Bars with asterisks are not significantly different from 'BTx3042', the susceptible check, according to Dunnett's test $(P<0.05)$. Sorghum genotypes are shown in order of lowest to highest disease severity in the dryland location for each year. 
nidia are capable of germinating on surfaces having a relatively broad range of available moisture. Depending upon host resistance, the volume of conidia germinating and being disseminated from microsclerotia is likely to be greater under conditions of free water availability, as occur under irrigation or heavy rainfall, although leaf wetness data was not taken. Rajasab and Ramalingam (26) found that dispersal of $R$. sorghi conidia from sporogenic microsclerotia was dependent upon both droplets and flowing water. In southern India, a greater number of conidia were disseminated on the Kharif crop (summer, monsoon) than the Rabi crop (winter, dry). Further experiments need to be conducted in order to differ- entiate the impact of free water upon sporogenic germination of microsclerotia and foliar infection by splash-disseminated conidia on surfaces of varying wetness.

Regardless of the year, irrigation had a dramatic impact upon disease severity. The relationship between disease severity in the irrigated nursery and microsclerotia production within lesions was positive but not significant. Thus, there was a trend for numbers of microsclerotia to increase in disease lesions as severity increased. Also, there was a positive but nonsignificant relationship between disease severity and microsclerotium size. For example, SC855, which did not differ in severity from BTx3042, the susceptible
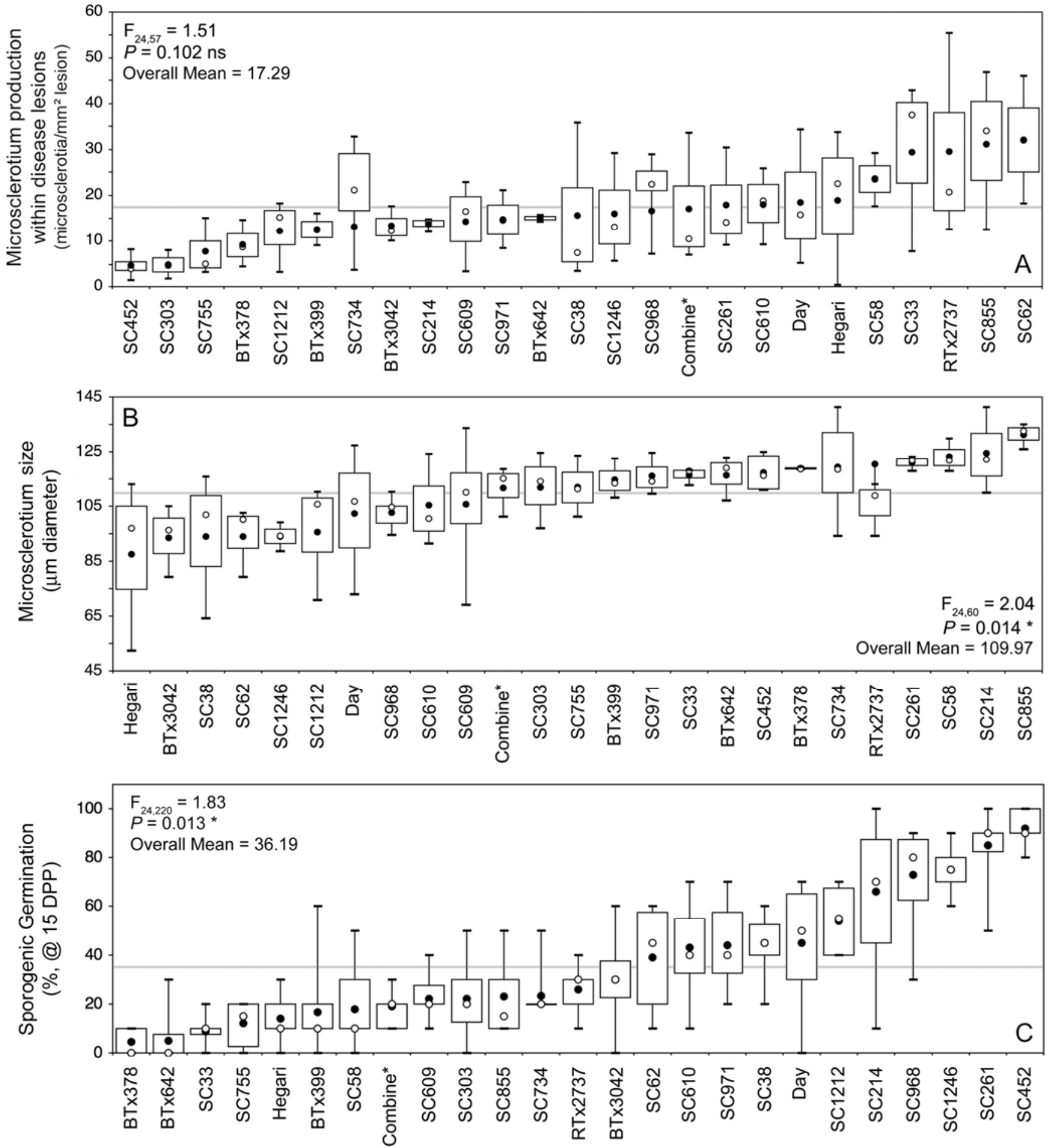

Fig. 4. Box plots of A, microsclerotium production; B, diameter (size); and C, sporogenic germination of Ramulispora sorghi from 25 sooty stripe-susceptible sorghum genotypes [ 'Combine' $=$ SN147(SA7078)] grown under irrigated conditions in Manhattan, KS in 2007. Filled and unfilled circles are median and mean values for sorghum genotypes, respectively. Light-shaded lines represent the overall mean across genotypes. Analysis of variance results within each panel are for the "genotype" term. 
check, had the largest microsclerotia of any genotype. More importantly, however, the more microsclerotia produced within a lesion, the larger their diameters. This phenomenon may be due to host responses which limit the lesion area in certain sorghum genotypes or the extent to which fungal tissue develops within lesions. Accumulation of sorghum pigments, which may include $3^{\prime}$-deoxyanthocyanidins, was observed within the lesions on several genotypes (Fig. 1) and may be a mechanism of host resistance.

However, large microsclerotia did not necessarily exhibit higher levels of sporogenic germination than small microsclerotia. In the case of SC855, microsclerotia from this genotype exhibited belowaverage sporogenic germination. SC452 was also highly susceptible but exhibited the lowest microsclerotium production and had

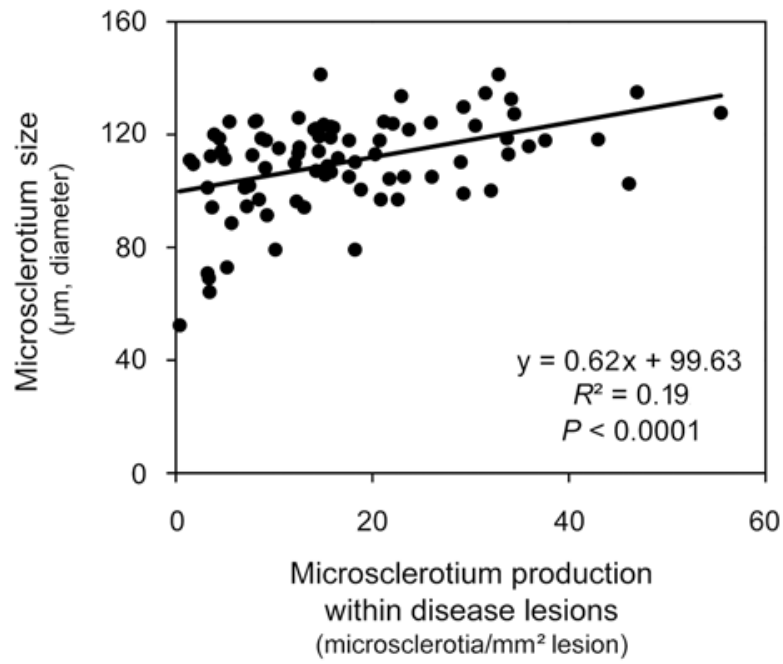

Fig. 5. Relationship between microsclerotium production within disease lesions (microsclerotia per square millimeter of lesion) and microsclerotium size (micrometers, diameter) in 25 genotypes from irrigated plots in the 2007 season. Each value (black circle) is derived from the microsclerotium count from one 6-mm-diameter $\left(28.3 \mathrm{~mm}^{2}\right)$ leaf disk obtained from the center of a sooty stripe lesion and the mean diameter of 30 microsclerotia from that leaf disk. Three to six leaf disks were evaluated for each genotype.

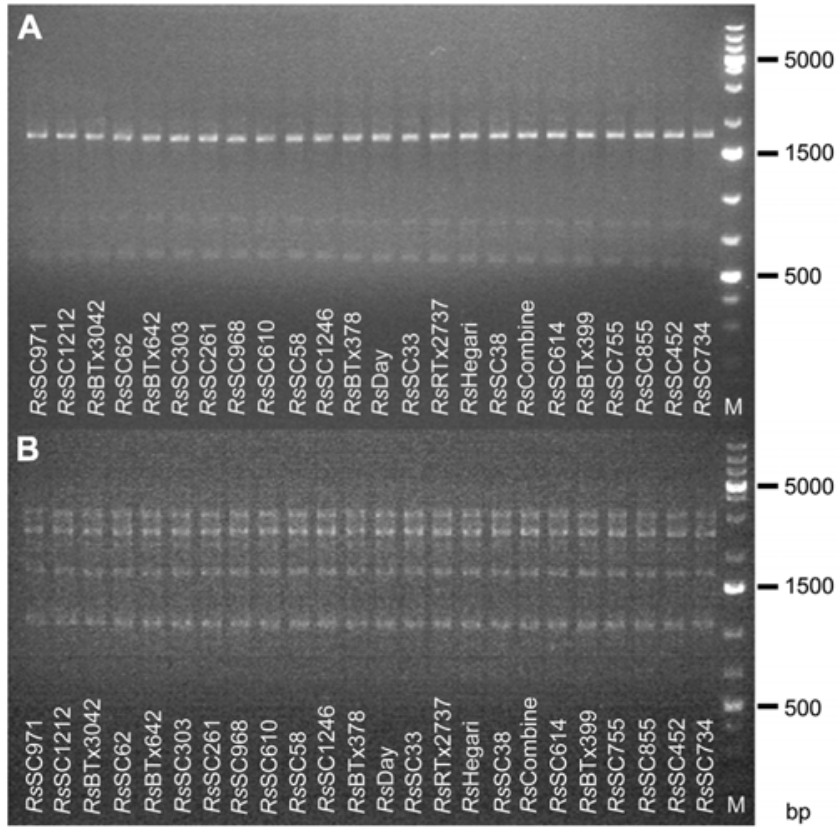

Fig. 6. Example agarose gels of random amplified polymorphic DNA polymerase chain reaction products. Lanes correspond to Ramulispora sorghi ("Rs") isolates from 24 sooty stripe susceptible sorghum genotypes ('RsSC609' was not included in the analysis) from the 2007 irrigated sorghum diversity panel planted in Manhattan, KS. Lane M, 1-kb DNA ladder. A, Primer OPE 2 and B, primer OPE 3. above-average microsclerotium size, yet the microsclerotia produced on this genotype had the highest level of sporogenic germination among all of the genotypes studied. Thus, there does not appear to be a relationship between microsclerotium size and sporogenic germination on artificial media. It is possible that the type of artificial media upon which the microsclerotia were incubated had a measureable impact upon sporogenic germination but this was not investigated.

The concept of inoculum potential and pathogen fecundity is manifest in the ability to produce viable propagules. In the field, inoculum potential and pathogen fecundity of $R$. sorghi is dependent upon foliar microsclerotia associated with leaf residue and resulting conidia production via sporogenic germination (22). Although sporogenic germination of microsclerotia has been measured, the understanding of the importance of microsclerotia themselves is limited compared with the importance of conidia dispersal as primary and secondary inocula derived from microsclerotia $(26,32)$. In this study, microsclerotia were assayed for sporogenic germination but not for the ability of these conidia to initiate new foliar infections in the field.

The impact of host resistance upon the ability of pathogens to produce primary and secondary inocula has been well studied. Subrahmanyam et al. (30) found that fewer Puccinia arachidis urediniospores were produced per unit area of lesion on resistant than susceptible peanut cultivars. Additionally, urediniospores harvested from lesions on resistant plants had reduced germinability. Bockus (2) indicated that control of cephalosporium stripe of wheat (Cephalosporium gramineum) was due to the deployment of moderately resistant cultivars, which resulted in reduced pathogen overseasoning and subsequent decrease of the disease over several years in Kansas. Marcroft et al. (16) showed that pseudothecium and ascospore production of Leptosphaeria maculans on canola (Brassica napus) stubble was significantly reduced in a resistant cultivar ('Surpass 400').

In order to test the hypothesis that the pathogen causing sooty stripe at the Ashland Bottoms location in Manhattan, KS consisted of one local, clonal fungal genotype and, thus, that differences in microsclerotium fecundity were due to plant and not pathogen genotype, a quick and inexpensive RAPD technique was employed. Isolates of $R$. sorghi collected from 25 sorghum genotypes grown in Manhattan were genetically identical (Fig. 5). Thus, differences in disease severity, microsclerotium production, diameter, and sporogenic germination were host genotype-dependent and not due to genetic differences in the local pathogen population. Additionally, ITS sequence fragments obtained from Kansas $R$. sorghi isolates were $100 \%$ identical to those sequences from the "Old World" isolates in South Africa (4). This finding is consistent with the concept that reproduction in $R$. sorghi is asexual in the field $(4,5,26)$.

The apparent lack of genetic variation in the local population of $R$. sorghi and the diversity of disease severity and microsclerotium properties indicate that host genotype plays a significant role in the ability of this pathogen to produce primary inoculum. This study indicates that screening for resistance is necessary in hybrid breeding programs, where consideration of pathogen inoculum potential should be coupled with plant selection based upon disease ratings.

\section{Acknowledgments}

We thank G. Odvody (Texas AgriLife Research and Extension Center, Corpus Christi) for initial advice concerning the growth and manipulation of $R$. sorghi. This work was supported in part by the Center for Sorghum Improvement, Kansas State University.

\section{Literature Cited}

1. Bantilan, M. C. S., Deb, U. K., Gowda, C. L. L., Reddy, B. V. S., Obilana, A. B., and Evenson, R. E., eds. 2004. Sorghum Genetic Enhancement: Research Process, Dissemination and Impacts. International Crops Research Institute for the Semi-Arid Tropics, Patancheru, India.

2. Bockus, W. W. 1998. Control strategies for stubble-borne pathogens of wheat. Can. J. Plant Pathol. 20:371-375.

3. Campbell, G. F., Janse, B. J., Marais, G. F., and Crous, P. W. 1996. Only one species of Ramulispora is associated with eyespot disease of wheat in 
South Africa. South Afr. J. Sci. 92:29-34.

4. Crous, P. W., Groenewald, J. Z., and Gams, W. 2003. Eyespot of cereals revisited: ITS phylogeny reveals new species relationships. Eur. J. Plant Pathol. 109:841-850.

5. Crous, P. W., Summerell, B. A., Carnegie, A. J., Wingfield, M. J., Hunter, G. C., Burgess, T. I., Andjic, V., Barber, P. A., and Groenewald, J. Z. 2009. Unravelling Mycosphaerella: do you believe in genera? Persoonia 23:99-118.

6. Dicko, M. H., Gruppen, H., Barro, C., Traore, A. S., van Berkel, W. J. H., and Voragen, A. G. J. 2005. Impact of phenolic compounds and related enzymes in sorghum varieties for resistance and susceptibility to biotic and abiotic stresses. J. Chem. Ecol. 31:2671-2688.

7. Farr, D. F., Bills, G. F., Chamuris, G. P., and Rossman, A. Y. 1989. Fungi on Plants and Plant Products in the United States. American Phytopathological Society, St. Paul, MN.

8. Hall, T. A. 1999. BioEdit: a user-friendly biological sequence alignment editor and analysis for Windows 95/98/NT. Nucleic Acids Symp. Ser. 41:95-98.

9. Haussmann, B. I. G., Hess, D. E., Sissoko, I., Kayentao, M., Reddy, B. V. S., Welz, H. G., and Geiger, H. H. 2001. Diallel analysis of sooty stripe resistance in sorghum. Euphytica 122:99-104.

10. Holliday, P. 1995. Fungus Diseases of Tropical Crops. Dover Publications, New York.

11. Jardine, D. J., and Gordon, W. B. 1997. Assessment of grain sorghum yield loss by sooty stripe (Ramulispora sorghi). (Abstr.) Phytopathology 87:S48.

12. JMP SAS. 2007. JMP Software: Release 7.0.1. SAS Institute Inc., Cary, $\mathrm{NC}$

13. Kerényi, Z., Zeller, K. A., Hornok, L., and Leslie, J. F. 1999. Molecular standardization of mating type terminology in the Gibberella fujikuroi species complex. Appl. Environ. Microbiol. 65:4071-4076.

14. Kiros-Meles, A., and Abang, M. M. 2008. Farmer's knowledge of crop diseases and control strategies in the regional state of Tigrai, northern Ethiopia: implications for farmer-researcher collaboration and disease management. Agric. Hum. Val. 25:433-452.

15. Lenné, J. 1990. A world list of fungal diseases of tropical pasture species. Phytopathol. Pap. 31:1-162.

16. Marcroft, S. J., Sprague, S. J., Salisbury, P. A., and Howlett, B. J. 2004. Potential for using host resistance to reduce production of pseudothecia and ascospores of Leptosphaeria maculans, the blackleg pathogen of Brassica napus. Plant Pathol. 53:468-474.

17. Marley, P. S., Diourté, M., Neya, A., Nutsugah, S. K., Sérémé, P., Katilé, S. O., Hess, D. E., Mbaye, D. F., and Ngoko, Z. 2002. Sorghum and pearl millet diseases in West and Central Africa. Pages 419-425 in: Sorghum and Millets Diseases, J. F. Leslie, ed., Iowa State Press, Blackwell Publishing, Ames.

18. Mbwaga, A. M., Pande, S., de Milliano, W. A. J., and Karunakar, J. 1993. Diseases and parasitic weeds of sorghum in Tanzania: occurrence and inci- dence, 1986-1990. Crop Prot. 12:183-188.

19. Murray, M. G., and Thompson, W. F. 1980. Rapid isolation of high molecular weight plant DNA. Nucleic Acids Res. 8:4321-4325.

20. Ngugi, H. K., King, S. B., Abayo, G. O., and Reddy, Y. V. R. 2002. Prevalence, incidence, and severity of sorghum diseases in western Kenya. Plant Dis. 86:65-70.

21. Nutsugah, S. K., Atokple, I. D. K., and Leth, V. 2008. Sorghum diseases prevalent in Ghana. Ghana J. Agric. Res. 40:119-126.

22. Odvody, G. N., and Dunkle, L. D. 1973. Overwintering capacity of Ramulispora sorghi. Phytopathology 63:1530-1532.

23. Odvody, G. N., Dunkle, L. D., and Boosalis, M. G. 1973. The occurrence of sooty stripe of sorghum in Nebraska. Plant Dis. Rep. 57:681-683.

24. Odvody, G. N., and Hepperly, P. R. 1992. Foliar diseases of sorghum. Pages 167-177 in: Sorghum and Millets Diseases, A Second World Review. W. A. J. de Milliano, R. A. Frederiksen, and G. D. Bengston, eds. ICRISAT, Patancheru, India.

25. Olive, L. S., Lefebvre, C. L., and Sherwin, H. S. 1946. The fungus that causes sooty stripe of Sorghum spp. Phytopathology 36:190-200.

26. Rajasab, A. H., and Ramalingam, A. 1989. Splash dispersal in Ramulispora sorghi Olive and Lefebreve, the causal organism of sooty stripe of sorghum. Proc. Indian Acad. Plant Sci. 99:335-341.

27. Roane, C. W., and Roane, M. K. 1996. Graminicolous fungi of Virginia: fungi associated with genera Aegilops to Digitaria. Va. J. Sci. 47:197-224.

28. Smith, C. W., and Frederiksen, R. A., eds. 2000. Sorghum: Origin, History, Technology, and Production. Wiley, New York.

29. Stack, J. P. 2002. Recurring and emerging sorghum diseases in North America. Pages 449-456 in: Sorghum and Millets Diseases, Iowa State Press, Blackwell Publishing, Ames.

30. Subrahmanyam, P., McDonald, D., and Subba Rao, P. V. 1983. Influence of host genotype on uredospore production and germinability in Puccinia arachidis. Phytopathology 73:726-729.

31. Thaung, M. M. 2008. A list of hyphomycetes (and agonomycetes) in Burma. Aust. Mycol. 27:149-172.

32. Thomas, M. D., Bocoum, F., and Thera, A. 1993. Field inoculations with sclerotia and conidia of Ramulispora sorghi formed in vivo. Mycologia 85:807-810.

33. Ullstrup, A. J., and Lavoilette, F. A. 1959. Diseases of corn and sorghum in Indiana. Plant Dis. Rep. 43:334-336.

34. White, T. J., Bruns, T. D., Lee, S., and Taylor, J. W. 1990. Amplification and direct sequencing of fungal ribosomal RNA genes for phylogenetics. Pages 315-322 in: PCR Protocols, A Guide to Methods and Applications. M. A Innis, D. H. Gelfand, J. J. Sninsky, and T. J. White, eds. Academic Press, San Diego, CA.

35. Xu, X., Claflin, L. E., Ramundo, B. A., and Jardine, D. J. 1995. Optimizing inoculum production for Ramulispora sorghi. (Abstr.) Phytopathology 85:1169. 